http://jmscr.igmpublication.org/home/ ISSN (e)-2347-176x ISSN (p) 2455-0450

crossref DOI: https://dx.doi.org/10.18535/jmscr/v8i2.55

\title{
A study to assess the knowledge among the nursing students regarding depression in Ganga Sheel school of nursing Bareilly (U.P) with a view to develop information pamphlet
}

\author{
Authors \\ Ina flora Singh ${ }^{1^{*}}$, Vaishali Bhardwaj ${ }^{2}$ \\ ${ }^{1}$ Assistant Professor, Ganga Sheel School of Nursing, Bareilly, Uttar Pradesh, India \\ ${ }^{2}$ Nursing Tutor, Ganga Sheel School of Nursing, Bareilly, Uttar Pradesh, India \\ *Corresponding Author \\ Miss Ina Flora Singh \\ Assistant Professor, Ganga Sheel School of Nursing, Bareilly, Uttar Pradesh, India
}

\begin{abstract}
Introduction: Depression in terms of its prevalence and the suffering, dysfunction, morbidity, and economic burden is a disorder of major public health importance. College students are a special group of people because in this period only, they are moving from adolescence to adulthood and can be one of the most stressful times in a person's life. Trying to maintain good grades, plan for the future, and be away from home often causes anxiety for a lot of students. Because of all these things some students get depressed.

Methodology: A Quantitative research approach with Descriptive research design was used for the study to assess the knowledge of nursing students on depression. The population comprised of nursing students. The study was conducted at Ganga Sheel School of nursing, Bareilly. Convenient Sampling technique was used to select the 30 subjects from the population. Self developed structured Knowledge questionnaire was used to assess the knowledge of nursing students on depression.

Results: The results of the study shows that $46.66 \%$ of nursing students were having average knowledge regarding depression.

Conclusion: The study results indicate that the nursing students were having average knowledge regarding depression. There is need to improve knowledge of nursing students regarding depression.

Keyswords: depression, knowledge, nursing students.
\end{abstract}

\section{Introduction}

Depression disturbs the way people evaluate and see themselves and changes the perception they have of others and the world, and it also affects their personal esteem. Self-esteem levels are personality constructs that result from intra and interpersonal relationships. They affect people's attitudes in their school activities, college life, at work and in every other daily activity ${ }^{1}$
Depression is a common mental health problem in adolescents worldwide, with an estimated 1 year prevalence of $4-5 \%$ in mid to late adolescence. Depression in adolescents is a major risk factor for suicide, the second-to-third leading cause of death in this age group, with more than half of adolescent suicide victims reported to have a depressive disorder at time of death. ${ }^{2}$ 


\section{JMSCR Vol||08 ||Issue ||02||Page 307-311||February}

A global public health concern Depression is a significant contributor to the global burden of disease and affects people in all communities across the world. Today, depression is estimated to affect 350 million people. Depressive disorder often starts at a young age. They reduce people's functioning and often are recurring. ${ }^{3}$

Depression in adolescents is more often missed than it is in adults, possibly because of the prominence of irritability, mood reactivity, and fluctuating symptoms in adolescents ${ }^{4}$

Because of depression prevalence, high mortality rates, suicide risk, and economic impact on the society, depression is a major public health issue. ${ }^{5}$ According to the fall 2007 American College Health Association-National College Health Assessment, a national survey of approximately 20,500 college students on 39 campuses, $43.2 \%$ of the students reported "feeling so depressed it was difficult to function" at least once in the past 12 months. More than 3,200 university students reported being diagnosed as having depression, with $39.2 \%$ of those students diagnosed in the past 12 months, $24.2 \%$ currently in therapy for depression, and $35.8 \%$ taking antidepressant medication. Among the students surveyed, 10.3\% admitted "seriously considering attempting suicide" within the past 12 months and $1.9 \%$ actually attempted suicide during that period. ${ }^{3}$
Family history of depression and exposure to psychosocial stress are the strongest risk factors for depression in adolescents. Inherited risks, developmental factors, sex hormones, and psychosocial adversity interact to increase risk through hormonal factors and associated perturbed neural pathways. ${ }^{2}$

\section{Materials and Methods}

A Quantitative research approach with Descriptive research design was used for the study to assess the knowledge of nursing students on depression. The population comprised of nursing students. Nursing students were selected from Ganga Sheel School of Nursing, Bareilly. Students of nursing , who were willing to give consent and participate in the study, who were available at the time of data collection were included in the study. The students of nursing were selected by Convenient Sampling technique. On the basis of standard sample size calculation total 30 subjects were recruited for the study. Self developed structured Knowledge questionnaire was used to assess the knowledge of nursing students on depression. After explaining the purpose of the study written consent was taken from the participants before starting data collection. Assurance was given to the subjects that the anonymity of each individual will be maintained.

\section{Result and Discussion}

Table No 1- Frequency and percentage distribution of nursing students according to socio- demographic variables.

\begin{tabular}{|c|c|c|c|c|}
\hline S.no. & \multicolumn{2}{|c|}{ Variables } & Frequency (f) & Percentage (\%) \\
\hline \multirow[t]{2}{*}{01} & \multirow[t]{2}{*}{ Gender } & Male & 05 & $16.6 \%$ \\
\hline & & Female & 25 & $83.3 \%$ \\
\hline \multirow[t]{3}{*}{02} & \multirow[t]{3}{*}{ AGE } & $<20$ years & 21 & $70 \%$ \\
\hline & & 20- 25 years & 24 & $80 \%$ \\
\hline & & $>25$ years & 0 & 0 \\
\hline \multirow[t]{3}{*}{03} & \multirow{3}{*}{$\begin{array}{l}\text { Marital } \\
\text { Status }\end{array}$} & Single & 29 & $96 \%$ \\
\hline & & Married & 01 & $3.3 \%$ \\
\hline & & $\begin{array}{l}\text { Separated } \\
\text { /Divorced }\end{array}$ & 0 & 0 \\
\hline \multirow[t]{5}{*}{04} & \multirow[t]{5}{*}{ Religion } & Hindu & 23 & $76.6 \%$ \\
\hline & & Muslims & 3 & $10 \%$ \\
\hline & & Christian & 01 & $3.3 \%$ \\
\hline & & Sikh & 03 & $10 \%$ \\
\hline & & Others & 0 & $0 \%$ \\
\hline
\end{tabular}




\begin{tabular}{|c|c|c|c|c|}
\hline \multirow[t]{3}{*}{05} & \multirow[t]{3}{*}{ Types of family } & Nuclear & 20 & $66.6 \%$ \\
\hline & & Joint & 10 & $33.3 \%$ \\
\hline & & Living alone & 0 & $0 \%$ \\
\hline \multirow[t]{2}{*}{06} & \multirow[t]{2}{*}{ Living Status } & With family & 16 & $53.35 \%$ \\
\hline & & $\begin{array}{l}\text { Without } \\
\text { family }\end{array}$ & 14 & $46.6 \%$ \\
\hline \multirow[t]{3}{*}{07} & \multirow[t]{3}{*}{ Family income } & $<20,000 /$ month & 15 & $50 \%$ \\
\hline & & $\begin{array}{l}20,000 \text { to } 30,000 / \\
\text { month }\end{array}$ & 06 & $20 \%$ \\
\hline & & $>30,000 /$ month & 09 & $30 \%$ \\
\hline \multirow[t]{4}{*}{08} & \multirow[t]{4}{*}{ Family problems } & Financial problem & 04 & $13.3 \%$ \\
\hline & & Social problem & 03 & $10 \%$ \\
\hline & & Personal problem & 18 & $60 \%$ \\
\hline & & All of the above & 05 & $16.6 \%$ \\
\hline \multirow[t]{4}{*}{09} & \multirow{4}{*}{$\begin{array}{l}\text { Place of } \\
\text { residence }\end{array}$} & Hostel & 24 & $80 \%$ \\
\hline & & Home of friend & 01 & $3.3 \%$ \\
\hline & & $\begin{array}{l}\text { Staying in rented } \\
\text { place }\end{array}$ & 0 & $0 \%$ \\
\hline & & $\begin{array}{l}\text { Staying in own } \\
\text { house }\end{array}$ & 05 & $16.6 \%$ \\
\hline \multirow[t]{4}{*}{10} & \multirow[t]{4}{*}{ Course of study } & B.sc nursing & 0 & $0 \%$ \\
\hline & & $\begin{array}{l}\text { Post Basic B.sc } \\
\text { Nursing }\end{array}$ & 0 & $0 \%$ \\
\hline & & GNM & 30 & $100 \%$ \\
\hline & & ANM & 0 & $0 \%$ \\
\hline
\end{tabular}

Table No. 1 Illustrates that approximately majority $25(83.3 \%)$ of participants were female and only $5(16.6 \%)$ were males. Maximum number of nurses students $24(80 \%)$ were in the age group of 20- 25 years, whereas $21(70 \%)$ were in the age group of $<20$ years and 0 in $>25$ years. Majority of the nurses students $29(96 \%)$ were single and only one $(3.3 \%)$ were married where as $0 \%$ are separated and divorced. Majority number of the nurses students $23(76.6 \%)$ were Hindu and $3(10 \%)$ were Muslim and 3(10\%) were Sikh and only $1(3.3 \%)$ were Christian whereas 0 in others. Two third of the nurses students 20(66.6\%) belong to nuclear family and one third $10(33.3 \%)$ belong to joint family, and $0 \%$ were living alone. Approximately half of the nurses students 16 $(53.35 \%)$ were living with family whereas 14 $(46.6 \%)$ were living without family. Half of the nurses students $15(50 \%)$ were having less than 20,000 /month income, whereas $6(20 \%)$ were having 20,000-30,000/ month, only $9(30 \%)$ were having more than $30,000 /$ month. $18(60 \%)$ nurses students were having personal problem, $5(16.6 \%)$ were having all personal problems financial problems and social problems, whereas $4(13.3 \%)$ were having financial problems and 3(10\%) were having social problem. Majority number of nurses students $24(80 \%)$ there place of residence was hostel, $5(16.6 \%)$ were staying in own house where as $1(3.3 \%)$ nurses students place of residence was there home of friend, and $0 \%$ were staying in rental place. $30(100 \%)$ were the student of the course of GNM who took part in the study, and 0\% were from B.sc nursing ,Post BasicB.sc nursing and ANM.

Table no. 2 Frequency and percentage distribution of knowledge level of nursing students on depression

$$
(\mathrm{N}=30)
$$

\begin{tabular}{|l|c|c|c|}
\hline Aspect & Category & Frequency & Percentage \% \\
\hline Poor & $5-7$ & 3 & $10 \%$ \\
\hline Average & $8-10$ & 14 & $46.66 \%$ \\
\hline Good & $11-13$ & 8 & $26.66 \%$ \\
\hline V.Good & $14-17$ & 5 & $16.66 \%$ \\
\hline
\end{tabular}


Table no. 2 reveals that, the knowledge level was average among $46.66 \%$ of nursing students on depression, $26.66 \%$ of nursing students were having good knowledge regarding depression,
$16.66 \%$ of nursing students were having very good knowledge regarding depression, and nearly $10 \%$ of the nursing students were having poor knowledge on depression

Table no 3: Association of Knowledge score and selected demographic variables among nursing students

$(\mathrm{N}=30)$

\begin{tabular}{|c|c|c|c|c|c|c|c|c|}
\hline $\begin{array}{l}\text { SL } \\
\text { NO. }\end{array}$ & $\begin{array}{l}\text { DEMOGRAPHIC } \\
\text { VARIABLES } \\
\end{array}$ & GOOD & AVERAGE & POOR & $\begin{array}{l}\text { CHI-S } \\
\text { CAL }\end{array}$ & $\begin{array}{c}\text { UARE } \\
\text { TAB }\end{array}$ & DF & SIGNIFICANCE \\
\hline $1-^{`}$ & $\begin{array}{l}\text { Gender } \\
\text { Male } \\
\text { Female }\end{array}$ & $\begin{array}{c}0 \\
25\end{array}$ & $\begin{array}{l}0 \\
0\end{array}$ & $\begin{array}{l}5 \\
0\end{array}$ & \multicolumn{2}{|c|}{$\begin{array}{l}27.76 \\
5.99\end{array}$} & 2 & NS $x^{2}$ \\
\hline $2-$ & $\begin{array}{l}\text { Age group } \\
<20 \text { years } \\
20-25 \text { years } \\
>25 \text { years }\end{array}$ & $\begin{array}{c}0 \\
21 \\
0\end{array}$ & $\begin{array}{l}0 \\
0 \\
0\end{array}$ & $\begin{array}{c}06 \\
03 \\
0\end{array}$ & 5.07 & 9.49 & 4 & NS ${ }^{x^{2}}$ \\
\hline 3- & $\begin{array}{l}\text { Marital status } \\
\text { Single } \\
\text { Married } \\
\text { Separated/divorced }\end{array}$ & $\begin{array}{c}29 \\
0 \\
0\end{array}$ & $\begin{array}{l}0 \\
1 \\
0\end{array}$ & $\begin{array}{l}0 \\
0 \\
0\end{array}$ & 37.33 & 5.99 & 2 & NS ${ }^{x^{2}}$ \\
\hline 4- & $\begin{array}{l}\text { Religion } \\
\text { Hindu } \\
\text { Muslim } \\
\text { Christian } \\
\text { Sikh } \\
\text { Others }\end{array}$ & $\begin{array}{l}23 \\
0 \\
\mathrm{O} \\
\mathrm{O} \\
0\end{array}$ & $\begin{array}{l}0 \\
0 \\
0 \\
0 \\
0\end{array}$ & $\begin{array}{l}0 \\
3 \\
1 \\
3 \\
0\end{array}$ & 45.59 & 15.51 & 6 & $\mathrm{NS} x^{2}$ \\
\hline $5-$ & $\begin{array}{l}\text { Types of family } \\
\text { Nuclear } \\
\text { Joint } \\
\text { Living alone }\end{array}$ & $\begin{array}{l}0 \\
0 \\
0\end{array}$ & $\begin{array}{l}20 \\
0 \\
0\end{array}$ & $\begin{array}{c}0 \\
10 \\
0\end{array}$ & 20.68 & 9.49 & 4 & NS ${ }^{x^{2}}$ \\
\hline 6- & $\begin{array}{l}\text { Living status } \\
\text { With family } \\
\text { Without family }\end{array}$ & $\begin{array}{l}0 \\
0\end{array}$ & $\begin{array}{l}16 \\
14\end{array}$ & $\begin{array}{l}0 \\
0\end{array}$ & 0 & 5.99 & 2 & NS $x^{2}$ \\
\hline $7-$ & $\begin{array}{l}\text { FAMILYINCOME } \\
<20,000 / \text { month } \\
20,000 \text { to } 30000 / \text { month } \\
>30,000 / \text { month }\end{array}$ & $\begin{array}{l}0 \\
0 \\
0\end{array}$ & $\begin{array}{c}15 \\
0 \\
0\end{array}$ & $\begin{array}{l}0 \\
6 \\
9\end{array}$ & 25 & 9.49 & 4 & NS ${ }^{x^{2}}$ \\
\hline $8-$ & $\begin{array}{l}\text { FAMILY PROBLEMS } \\
\text { Financial problem } \\
\text { Social problem } \\
\text { Personal problem } \\
\text { All of above }\end{array}$ & $\begin{array}{l}0 \\
0 \\
0 \\
0\end{array}$ & $\begin{array}{c}0 \\
0 \\
18 \\
0\end{array}$ & $\begin{array}{l}4 \\
3 \\
0 \\
5\end{array}$ & 25.8 & 12.59 & 6 & NS $x^{2}$ \\
\hline 9- & $\begin{array}{l}\text { Place of residence } \\
\text { Hostel } \\
\text { Home of friend } \\
\text { Staying in Rental Place } \\
\text { Staying in Own house }\end{array}$ & $\begin{array}{c}24 \\
0 \\
0 \\
0 \\
\end{array}$ & $\begin{array}{l}0 \\
1 \\
0 \\
5\end{array}$ & $\begin{array}{l}0 \\
0 \\
0 \\
0\end{array}$ & 30 & 12.59 & 6 & NS ${ }^{x^{2}}$ \\
\hline $10-$ & $\begin{array}{l}\text { Course of study } \\
\text { GNM } \\
\text { B.sc nursing } \\
\text { Post basic B.sc nursing } \\
\text { ANM }\end{array}$ & $\begin{array}{c}30 \\
0 \\
0 \\
0\end{array}$ & $\begin{array}{l}0 \\
0 \\
0 \\
0\end{array}$ & $\begin{array}{l}0 \\
0 \\
0 \\
0\end{array}$ & 30 & 12.59 & 6 & NS $x^{2}$ \\
\hline
\end{tabular}

Table no.3 shows that there is no significant association between knowledge score and gender, age group, marital status, religion, types of family, living status, family income, family problem, place of residence, course of study 


\section{JMSCR Vol||08||Issue||02||Page 307-311||February}

\section{Conclusion}

The study results indicate that the nursing students were having average knowledge regarding depression. There is need to improve knowledge of nursing students regarding depression.

Ethical clearance: Ethical committee permission was obtained from the Ethical committee of Ganga Sheel School of nursing, Bareilly.

\section{Source of Funding: Self}

\section{Conflict of Interest- Nil}

\section{References}

1. Adeosun I.I, Adolescents students knowledge of depression and appropriate help-seeking in Nigeria (Internet), International Neuropsychiatric Disease Journal, 2016, (cited on - May 2018), Volume no.-6(3. issue no.- 2321-7235, Page no.- 1-6.

2. Prof Thapar A, Collisaw S, Pine D S, Thapar A K, Depression in adolescence. (Internet). THE LANCET. Publication year02 February 2012. Cited on-May 2018. Volume no- 379, Issueno-9820.Pageno1056-1067.

3. Kamenev K, Mellor-Maras B, Leal I; Ayuso-Mateos J L, Cabello M ,Analysing Psychosocial Difficulties in Depression: A Content Comparison between Systematic Literature Review and Patient Perspective(Internet) Biomed research international 2014 June 9, (cited on -May 2018) Issue no- 319634.

4. Cabello M., Marsa B. M., Sabariego. C., Cieza. A., Mateos J. L.A., Psychosocial Features of depression: A systematic literature review(Internet), Publication yearDecember 1, 2012, cited on- May 2018, Volume no- 141, issue no- 1, Pages- 22-33.
5. Grover S, Dutt A, Avasthi A, An overview of Indian research in Depression(internet), Indian Journal of Psychiatry , Jan 2010, (cited on may 2018), Volume no.- 52 , Page no. $-178-188$. 